\title{
APPLICATION OF PHYTOTECHNOLOGY IN DETERMINING PLANT SPECIES FOR GREENSPACE IN THE CITY OF PALANGKA RAYA
}

\author{
Yetrie Ludang \\ Department of Forestry, Faculty of Agriculture, Palangka Raya University, \\ Palangka Raya, Indonesia.
}

\begin{abstract}
This study aims to obtain scientific evidence for plant species in their ability to absorb carbon dioxide, to rank plants based on their ability to absorb carbon dioxide, and to obtain the format of area and distribution. Experimental methods of plant species based on the types that have been commonly used as urban greening, and traditionally based plant species. The results obtained indicate that plant-based types of local wisdom are scientifically proven to show superiority in the rate of carbon dioxide absorption. There are plant species, both local wisdom and urban greening plants, which have specific fluctuating absorption rates.
\end{abstract}

Keywords: greenspace, plant species, local wisdom, carbon dioxide absorption

Cite this Article: Yetrie Ludang, Application of Phytotechnology in Determining Plant Species for Greenspace in the City of Palangka Raya, International Journal of Advanced Research in Engineering and Technology (IJARET), 11 (1), 2020, pp 1-6. http://iaeme.com/Home/issue/IJARET?Volume=11\&Issue=1

\section{INTRODUCTION}

Naturally, green open space (RTH) is an carbon dioxide-absorbing ecosystem, because only plants need it. With this natural principle, the area of green open space should increase in line with the increase in carbon dioxide emissions. However, many facts show that the area of green space is getting narrower, making the conditions unrealistic to overcome the increase in carbon dioxide. Legally, there are existing laws and government regulations (Inmendagri Number 14 of 1988, Law Number 41 of 1999, PP Number 63 of 2002, Law Number 26 of 2007 ) is based on the percentage of green space (10-40\%) of land area (watershed, region, city). This condition states the availability of land for non-green space (transportation, housing, commercial, industrial, etc.) is limited (60-90\%) and permanent.

General facts show the population and activities continue to grow, the implication is the development of non-green infrastructure. Both the increase in population and the development of non-green open infrastructure resulted in an increase in carbon dioxide emissions into the air. In general, the development of non-green space infrastructure and an increase in carbon dioxide emissions over a certain area of fixed green space have and will lead to a reduction in 
the capacity of green space to absorb carbon dioxide. Specified area / fixed green space does not follow the nature. Realistic conditions at this time global warming has occurred.

Based on the population approach, Samudro \& Mangkoedihardjo (2006) formulated green space in two settings: 1) the extent of the area of green space absorbing carbon dioxide decreases. The meaning is for a fixed / certain area, then the ability of green space to absorb carbon dioxide is decreasing in line with an increase in population. Also, the area of green open space is increasing, which means to maintain the ability of green open space to absorb carbon dioxide, then the area of green open space must increase in line with an increase in population. 2) distribution rules regarding the distribution of green space following the natural conditions of the environment and their use (geography, topography, water bodies, urban / regional infrastructure).

The population approach is realistic and follows nature, but does not yet involve biodiversity to meet the sustainable environmental sanitation of the United Nations (Annan, 2002). Furthermore, it is necessary to approach the knowledge of local wisdom through the development of green diversity. The new problem formulation is utilizing the types of plants that can be accepted by local custom; assess the level of carbon dioxide uptake by local plant species and other general green space plants; determine the extent and distribution of green space

This study aims to obtain scientific evidence for plant species in their ability to absorb carbon dioxide, to rank plants based on their ability to absorb carbon dioxide, and to obtain the format of area and distribution.

The results can be used to contribute to the development of environmental science, especially in the field of Fitotechnology science; the application of biodiversity in green space to strengthen the concept of sustainable environmental sanitation from the UN; scientific sources for policy consideration, regulation and implementation of green open space, both local and national.

\section{METHODS}

\subsection{Study Area}

Palangka Raya City covers 5 districts, namely Pahandut, Jekan Raya, Bukit Batu, Sebangau and Rakumpit Districts.

\subsection{Study Subjects}

- Dayak tribal community respondents 2-3 generations who lived permanently and did not mix with other tribes.

- Types of plants

o Base local wisdom 6 types of plants:

- Has economic value and as traditional medicine, Jackfruit (Artocarpus heterophyllus Lam.) and Yellow Coconut (Cocoseburen)

- Functioning as an ornamental plant, Red Areca (Cyrtostachys lakka Becc.)

- Has flowers: Cananga (Canangium odoratum (Lamk.) Hook. and Thorms. (Lat.)

- Functioning as a food plant and traditional medicine, Papaya (Carica papaya L.) and Lemongrass (Cymbopogoncitratus) 


\section{Yetrie Ludang}

o Common plants RTH 6 types of plants:

- Functioning as a protective plant, Trembesi (Samanea saman (Jacq.) Merr.) and Tanjung (Mimusops elengi L.)

- Functioning as an ornamental plant, Japanese Bamboo (Dracaena surculosa Lindl.)

- Has economic value, Rambutan (Nephelium lappaceum L.) and Mango (Mangifera indica L.)

- Functioning as a traditional medicinal plant, Pasak Bumi (Eurycoma longifoliaJack.).

\subsection{Experiment}

- Field (Fig.1):

○ Daily: placement of plants in transparent hoods within 1 hour, measuring carbon dioxide absorption levels every 5 minutes. Repetition is done 2 times a day, morning and evening. All plants are planted in pots containing garden soil and compost (Mangkoedihardjo and April, 2012).

○ Weekly: daily experiments are carried out 2 times a week.

- Seasonal: weekly experiments conducted for the dry and rainy seasons.

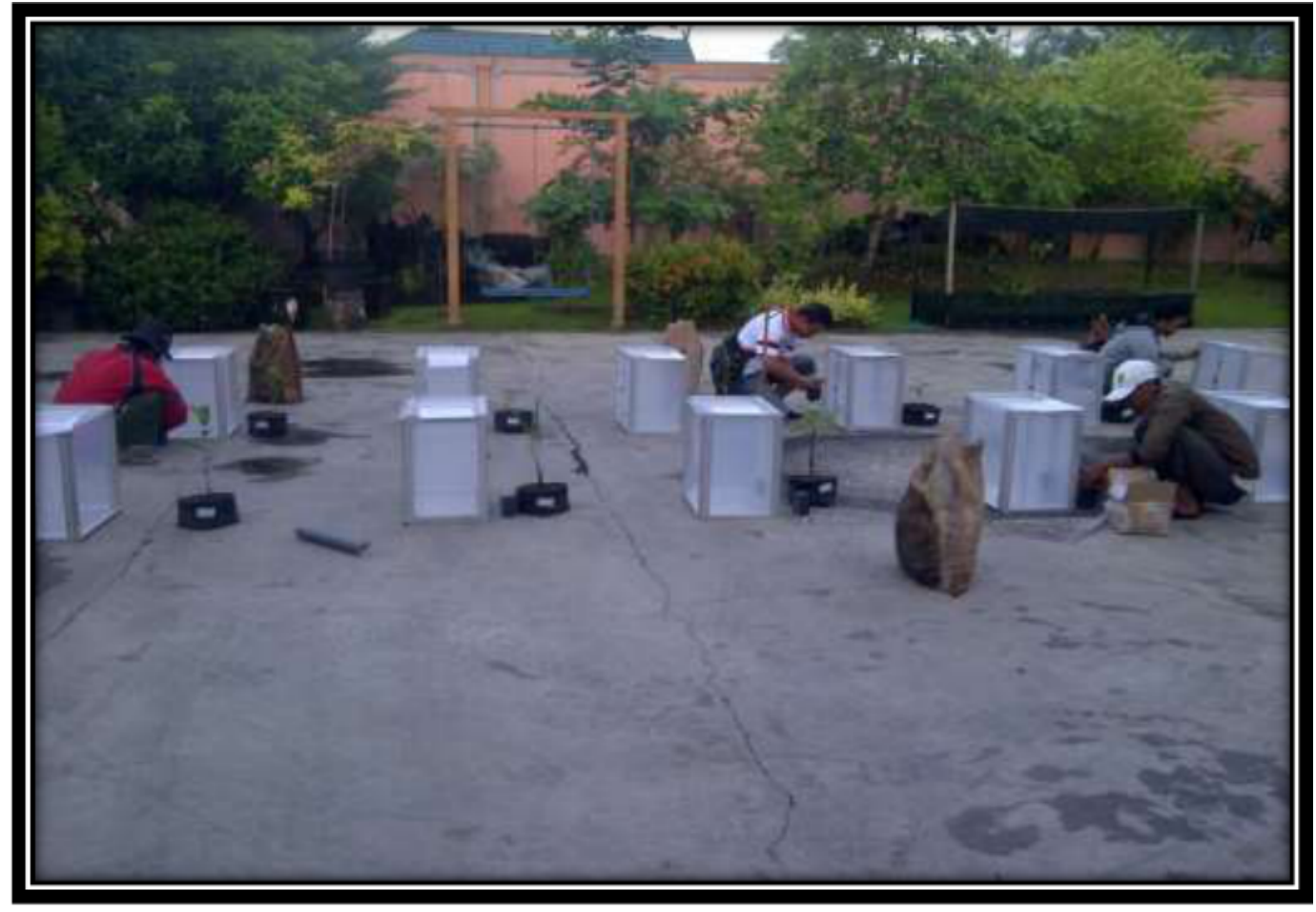

Figure 1 Field experiment for carbon dioxide absorption by plants

- BPPT Cepu Laboratory:

o Analysis of carbon dioxide using Gas Chromatography

o Gravimetric analysis of plant dry weight. 
Application of Phytotechnology in Determining Plant Species for Greenspace in the City of Palangka Raya

\section{RESULTS AND DISCUSSION}

Table 1. Plant species ranking

\begin{tabular}{|c|c|c|c|c|}
\hline Ranking & Plant species & Scientific name & \begin{tabular}{|c|} 
CO2 specific \\
absorption rate (mg \\
$/ \mathrm{m} 2 /$ minute)
\end{tabular} & Plant origin \\
\hline 1 & Red areca nut & $\begin{array}{l}\text { Cyrtostachys lakka } \\
\text { Becc. }\end{array}$ & 1.37 & Local \\
\hline 2 & Lemongrass & Cymbopogon citratus & 1.35 & Local \\
\hline 3 & Papaya & Carica papaya L. & 1.29 & Local \\
\hline 4 & Reminisced & $\begin{array}{l}\text { Canangium odoratum } \\
\text { (Lamk.) Hook. and } \\
\text { Thorms. (Lat.) }\end{array}$ & 1.22 & Local \\
\hline 5 & Japanese Bamboo & $\begin{array}{l}\text { Dracaena surculosa } \\
\text { Lindl. }\end{array}$ & 1.22 & $\begin{array}{l}\text { Common plant for } \\
\text { greening }\end{array}$ \\
\hline 6 & Trembesi & $\begin{array}{l}\text { Samanea saman } \\
\text { (Jacq.) Merr. }\end{array}$ & 1.19 & $\begin{array}{l}\text { Common plant for } \\
\text { greening }\end{array}$ \\
\hline 7 & Tanjung & Mimusops elengi L. & 1.11 & $\begin{array}{l}\text { Common plant for } \\
\text { greening }\end{array}$ \\
\hline 8 & Pasak Bumi & $\begin{array}{l}\text { Eurycoma longifolia } \\
\text { Jack. }\end{array}$ & 1.10 & $\begin{array}{l}\text { Common plant for } \\
\text { greening }\end{array}$ \\
\hline 9 & Mango & Mangifera indica $\mathrm{L}$. & 0.88 & $\begin{array}{l}\text { Common plant for } \\
\text { greening }\end{array}$ \\
\hline 10 & Rambutan & $\begin{array}{l}\text { Nephelium lappaceum } \\
\text { L. }\end{array}$ & 0.54 & $\begin{array}{l}\text { Common plant for } \\
\text { greening }\end{array}$ \\
\hline 11 & Yellow Coconut & Cocoseburen & 0.47 & Local \\
\hline 12 & Jackfruit & $\begin{array}{l}\text { Artocarpus } \\
\text { heterophyllus Lam. }\end{array}$ & 0.43 & Local \\
\hline
\end{tabular}

\section{Discussion}

- The specific absorption rate represents the rate of carbon dioxide absorption ( $\mathrm{mg} / \mathrm{min}$ ) per unit area of the green space (in this study, green space ecosystems are in the form of hoods).

- For a number of selected plant species the fact is that more local plants are superior in absorbing carbon dioxide (Jaya et al., 2018; Ludang et al., 2018).

- Because of the nature of local wisdom, the superiority of the plant species is "sitespecific" and cannot be compared with other types of plants.

Table 2. Carbon dioxide specific absorption rate in hourly intervals on a clear day

\begin{tabular}{|c|c|c|c|c|c|}
\hline \multirow[b]{2}{*}{ No } & \multirow[b]{2}{*}{ Plant species } & \multicolumn{4}{|c|}{ CO2-specific absorption rate $(\mathrm{mg} / \mathrm{m} 2 / \mathrm{min})$ at day time intervals } \\
\hline & & $\begin{array}{c}\text { 6.00-6.30 } \\
\text { WESTERN } \\
\text { INDONESIA } \\
\text { TIME }\end{array}$ & $\begin{array}{c}\text { 9.00-9.30 } \\
\text { WESTERN } \\
\text { INDONESIA } \\
\text { TIME }\end{array}$ & $\begin{array}{c}\text { 12.00-12.30 } \\
\text { WESTERN } \\
\text { INDONESIA } \\
\text { TIME }\end{array}$ & $\begin{array}{c}\text { 15.00-15.30 } \\
\text { WESTERN } \\
\text { INDONESIA } \\
\text { TIME }\end{array}$ \\
\hline & Local & & & & \\
\hline 1 & Jackfruit & 0.45 & -0.61 & -0.07 & 1.96 \\
\hline 2 & Red areca nut & 1.93 & 1.33 & -0.46 & 2.68 \\
\hline 3 & Papaya & 1.15 & 1.48 & 0.53 & 2.00 \\
\hline 4 & Reminisced & 2.19 & 1.00 & 0.58 & 1.13 \\
\hline 5 & Yellow Coconut & -0.04 & 0.99 & 0.18 & 0.75 \\
\hline 6 & Lemongrass & 1.24 & 1.56 & 1.39 & 1.23 \\
\hline
\end{tabular}




\begin{tabular}{|l|l|r|r|r|r|} 
& $\begin{array}{l}\text { Common plant for } \\
\text { greening }\end{array}$ & & & & \\
\hline 7 & Japanese Bamboo & 1.73 & 0.16 & 1.29 & 1.70 \\
\hline 8 & Tanjung & 1.92 & 1.29 & 0.20 & 1.01 \\
\hline 9 & Trembesi & 1.56 & -0.14 & 0.34 & 3.03 \\
\hline 10 & Rambutan & -1.13 & 0.93 & 0.67 & 1.69 \\
\hline 11 & Mango & 1.63 & 0.66 & -0.54 & 1.77 \\
\hline 12 & Pasak Bumi & 1.60 & 0.12 & 0.61 & 2.08 \\
\hline
\end{tabular}

\section{Discussion}

- Specific negative absorption rate (-) indicates that carbon dioxide specific absorption rate has decreased.

- Both plant categories (local and general green space) indicate the presence of plant species, which have decreased specific rates at certain time intervals in the day.

- Not yet known / reported by other similar studies, which produce specific absorption rate fluctuations. So, the results above are new findings.

- These facts reinforce the need and importance of biodiversity in a green space ecosystem (Jaya et al., 2018; Ludang et al., 2018).

\section{Placement of plant species implementation}

- Addition of local plant species to existing green space, to increase the specific absorption rate of carbon dioxide.

- Distribution of green space according to the structure and function of land use.

\section{CONCLUSIONS}

For selected plant species in this study, local wisdom-based plant types have been scientifically proven to show superiority in the rate of carbon dioxide absorption. There are types of plants, both local wisdom and general green space plants, which have specific fluctuative absorption rate characteristics. Therefore, simultaneous planting (diversity of species in a green space) can complement each other's advantages and disadvantages of each plant species.

Based on the results of the study can be suggested as follows:

a. Recommendations for plant species for the distribution of greenspace in Palangka Raya are Red Areca, Lemongrass, Cananga, Japanese Bamboo, Trembesi and Tanjung.

b. Need further research on the number of plants recommended for the development of green space in Palangka Raya City.

c. Palangka Raya City Government should prioritize plants that have high $\mathrm{CO} 2$ absorption, have economic and aesthetic value to ensure the concept of biodiversity of Palangka Raya City.

d. Law Number 26 of 2007 regarding spatial planning needs to be reviewed again.

\section{REFERENCES}

[1] Annan, KA., (2002), Toward A Sustainable Future. Environment, 44 (7): 10-15. ProQuest, USC, Los Angeles, 8 May 2004. Available at http://www.proquest.com

[2] Government Regulation Number 63 Year 2002, concerning Urban Forests.

[3] Instruction of the Minister of Home Affairs No. 14 of 1988 concerning the Arrangement of Green Open Spaces in Urban Areas. 
Application of Phytotechnology in Determining Plant Species for Greenspace in the City of Palangka Raya

[4] Jaya, H.P., Fernando, Ludang, Y. (2018). Lakes and forests as a couple of environmental infrastructure in tropical countries. International Journal of Civil Engineering and Technology, 9(7): 1270-1275.

[5] Law of the Republic of Indonesia Number 26 of 2007, concerning Spatial Planning.

[6] Law of the Republic of Indonesia Number 41 of 1999 concerning Forestry.

[7] Ludang, Y., Supriyati, W., Alpian (2018). Assessment of saplings of mangosteen (Garcinia Mangostana L) in absorbing carbon dioxide. International Journal of Civil Engineering and Technology, 9(11): 408-414.

[8] Mangkoedihardjo, S. and April, SAL. (2012). Compost On Evapotranspiration Bed Planted With Yellow Flag For Treatment Of Wastewater Containing Anionic Surfactant. Journal of Applied Sciences Research, 8(3): 1630-1633.

[9] Samudro, G. and S. Mangkoedihardjo, (2006), Water Equivalent Method for City Phytostructure of Indonesia. International Journal of Environmental Science and Technology, 3 (3): 261-267. 